\title{
GGE BIPLOT ANALYSIS TO RECOMMEND COWPEA CULTIVARS FOR GREEN GRAIN PRODUCTION ${ }^{1}$
}

\author{
LEANE FIALHO DE MELO ${ }^{2 *}$, MARCELO DE SOUSA PINHEIRO ${ }^{2}$, RENATA FERNANDES DE MATOS ${ }^{2}$, JÚLIO \\ CÉSAR DOVALE ${ }^{2}$, CÂNDIDA HERMÍNIA CAMPOS DE MAGALHÃES BERTINI ${ }^{2}$
}

\begin{abstract}
Genotypes can respond differently to environments; thus, studies on adaptability and production stability are important to assist breeders in the identification and recommendation of cultivars. The objective of this work was to determine the adaptability and production stability of cowpea genotypes focused on subsidize recommendations of cultivars for green grain production in the state of Ceará, Brazil. Five assays were conducted in different locations in two climatic regions of the state of Ceará: a tropical mild hot semiarid region encompassing the municipalities of Acaraú, Pentecoste, and Crato, and a tropical hot semiarid region encompassing the municipalities of Mauriti and Madalena. Twenty cowpea genotypes-12 elite lines and 8 cultivars-were evaluated for cultivation value and use, using a randomized block design, with four replications. The results were subjected to analyses of variance and adaptability and green grain yield stability analyses by GGE biplot multivariate analysis. The effects of genotypes, environments, and $\mathrm{G} \times \mathrm{E}$ were significant, denoting different responses of genotypes in different locations. The results of the adaptability and stability analyses by the GGE biplot method showed that the two principal components explained $72.17 \%$ of the total variation, allowing reliable bidimensional projections. The municipality of Crato was the ideal location for tests and the lines MNC05-847B-123 and MNC00-595F-27 showed good production, adaptation, and stability, and can be recommended for green grain production in the state of Ceará, Brazil.
\end{abstract}

Keywords: Vigna unguiculata. Genotype $\times$ environment interaction. Grain yield. Cultivation value and use.

\section{PROJEÇÃO GGE BIPLOT NA RECOMENDAÇÃO DE CULTIVARES DE FEIJÃO-CAUPI PARA PRODUÇÃO DE GRÃOS VERDES}

\begin{abstract}
RESUMO - Genótipos podem responder aos ambientes de forma diferente; por isso, o estudo de adaptabilidade e estabilidade produtiva é importante para auxiliar melhorista na identificação e recomendação de cultivares. Assim, o objetivo deste trabalho foi inferir acerca da adaptabilidade e estabilidade produtiva de genótipos de feijão-caupi visando subsidiar a recomendação de cultivares para a produção de grãos verdes no estado do Ceará. Para isto, foram conduzidos cinco ensaios de valor de cultivo e uso (VCU) em localidades distintas pertencentes à duas regiões climáticas do estado do Ceará: Tropical quente semiárido brando (Acaraú, Pentecoste e Crato) e Tropical quente semiárido (Mauriti e Madalena). Foram avaliados 20 genótipos de feijãocaupi, sendo 12 linhagens elite e oito cultivares, em delineamento de blocos casualizados, com quatro repetições. Foram realizadas análises de variância e em seguida análises de adaptabilidade e estabilidade da produtividade de grãos verdes por meio da técnica multivariada GGE biplot. Os efeitos de genótipos, ambientes e interação $\mathrm{G} \times \mathrm{E}$ foram significativos, evidenciando respostas diferenciadas dos genótipos nas diferentes localidades. No aprofundamento das análises de adaptabilidade e estabilidade, os resultados do método GGE biplot revelaram que os dois primeiros componentes principais explicaram $72,17 \%$ da variação total, permitindo projeções bidimensionais fidedignas. A cidade de Crato foi indicada como local ideal para teste e as linhagens MNC05-847B-123 e MNC00-595F-27 se mostraram produtivas, adaptadas e estáveis, devendo serem recomendadas para produção de grãos verdes no estado do Ceará.
\end{abstract}

Palavra-chaves: Vigna unguiculata. Interação genótipos x ambientes. Produtividade de grãos. Ensaios de valor de cultivo e uso (VCUs).

\footnotetext{
${ }^{*}$ Corresponding author

${ }^{1}$ Received for publication in $04 / 03 / 2019$; accepted in $02 / 13 / 2020$.

Paper extracted from the doctoral thesis of the first author.

${ }^{2}$ Departmet of Phytotechnics, Universidade Federal do Ceará, Fortaleza, CE, Brazil; leane fialho@yahoo.com.br - ORCID: 0000-00032500-0712, marcelospufc@gmail.com - ORCID: 0000-0002-1511-8808, renatafmatos@hotmail.com - ORCID: 0000-0003-4394-5218, juliodovale@ufc.br - ORCID: 0000-0002-3497-9793, candica@ufc.br - ORCID: 0000-0003-2949-5660.
} 


\section{INTRODUCTION}

Cowpea (Vigna unguiculata (L.) Walp.) green grains (immature grains) are very appreciated by people of the Northeast region of Brazil, and is part of several local typical dishes. Thus, the cowpea green grain market is traditional in the Northeast region, and is growing in other capitals of North, Southeast, and Center-West regions of Brazil (SOUSA et al., 2015). The state of Ceará is probably the greatest producer and consumer of green grains in the Northeast region; the cowpea marketed volume in 2016 reached $2.887 .7 \mathrm{Mg}$ (CEASA, 2018), denoting a great demand of this product in the state.

The green-grain cowpea (pods and immature grains) is an attractive market due to its great volume, but little information is found regarding its production by family farmers (predominant) or agribusiness entrepreneurships (FREIRE FILHO et al., 2017). However, the Brazilian market is poor in improved cultivars for green grain production (ROCHA et al., 2012). Despite many genetic materials used for dry grain production are used for green grain production, there are a recent demand of supermarket and restaurant chains for green-grain cowpea that presents longer shelf-life and preserve its visual characteristics after cooking, which usually is not found when using conventional cultivars for dry grain production (ROCHA, 2009).

The commercial success of a cultivar is related to its agronomical performance in a broad crop region (SOUSA et al., 2018). Thus, cowpea breeding programs annually test several genotypes in different environments before recommend them (SANTOS et al., 2014). However, these evaluations of genotypes in different environments usually face an additional component that affects phenotypic values, which is the genotype-environment interaction $(\mathrm{G} \times \mathrm{E})$ (CRUZ; CARNEIRO; REGAZZI, 2014).

The $\mathrm{G} \times \mathrm{E}$ occurs when the relative performance of genotypes is not consistent from one environment to the other, and such inconsistency is caused by different responses of a same set of genes to environmental changes, or expression of different set of genes in different environments (MUTHONI; SHIMELIS; MELIS, 2015). The $\mathrm{G} \times \mathrm{E}$ cannot be avoided (ADEWALE et al., 2010) and its occurrence hinders the selection of genotypes (CARVALHO et al., 2016). One of the alternatives recommended to attenuate the effect of this interaction is the use of cultivars with broad adaptability and good stability (CRUZ; CARNEIRO; REGAZZI, 2014).

The stability analysis is an important tool for plant breeders to identify and recommend genotypes widely or specifically adapted for target environments (MUTHONI; SHIMELIS; MELIS, 2015). A genotype is adapted and stable when advantageously use the environmental effects and when its development is predictable in an environment (ROCHA et al., 2012).

Several methodologies are used to evaluate the $\mathrm{G} \times \mathrm{E}$ and determine the adaptability and production stability of genotypes. One of the most used method in genetic studies is the GGE biplot. This model explores efficiently the $\mathrm{G} \times \mathrm{E}$, with high accuracy in the identification of mega-environments and in the selection of stable and adapted genotypes to specific environments (SILVA; BENIN, 2012).

In this context, the objective of this work was to determine the adaptability and production stability of cowpea genotypes focused on subsidize recommendations of cultivars for green grain production in the state of Ceará, Brazil.

\section{MATERIAL AND METHODS}

Five cultivation value and use assays were conducted in different locations in two climatic regions of the state of Ceará, Brazil (Table 1, Figure 1) from 2015 to 2017 . Twenty cowpea genotypes12 elite lines and 8 cultivars - were evaluated. These genotypes were from the Active Germplasm Bank of the Cowpea Breeding Program of the Embrapa Mid-North, in partnership with the Federal University of Ceará (Table 2). The cultivars Vagem Roxa-THE, Azulão-MS, and Sempre Verde-CE, usually grown for green-grain cowpea production were used as controls (SOUSA et al., 2015).

Table 1. Location of the areas in the state of Ceará, Brazil, where the experiments were conducted, and their respective sowing times, geographic coordinates, rainfall depths, and mean annual temperatures.

\begin{tabular}{ccccccr}
\hline Location & Sowing times & Altitude & Latitude & Longitude & Rainfall depths ${ }^{*}$ & Temperatures \\
\hline Acaraú & $23 / 03 / 2015$ & $16.5 \mathrm{~m}$ & $02^{\circ} 53^{\prime} \mathrm{S}$ & $40^{\circ} 08^{\prime} \mathrm{W}$ & $308.1 \mathrm{~mm}$ & $27.7^{\circ} \mathrm{C}$ \\
Pentecoste & $12 / 04 / 2016$ & $45 \mathrm{~m}$ & $03^{\circ} 49^{\prime} \mathrm{S}$ & $39^{\circ} 20^{\prime} \mathrm{W}$ & $98.2 \mathrm{~mm}$ & $26.4^{\circ} \mathrm{C}$ \\
Crato & $24 / 08 / 2016$ & $427 \mathrm{~m}$ & $07^{\circ} 14^{\prime} \mathrm{S}$ & $39^{\circ} 22^{\prime} \mathrm{W}$ & $12.8 \mathrm{~mm}$ & $21.1^{\circ} \mathrm{C}$ \\
Mauriti & $01 / 02 / 2017$ & $453 \mathrm{~m}$ & $07^{\circ} 23^{\prime} \mathrm{S}$ & $38^{\circ} 41^{\prime} \mathrm{W}$ & $172.0 \mathrm{~mm}$ & $25.2^{\circ} \mathrm{C}$ \\
Madalena & $25 / 02 / 2017$ & $353 \mathrm{~m}$ & $04^{\circ} 47^{\prime} \mathrm{S}$ & $39^{\circ} 39^{\prime} \mathrm{W}$ & $168.8 \mathrm{~mm}$ & $25.9^{\circ} \mathrm{C}$ \\
\hline
\end{tabular}

${ }^{*}$ Rainfall depths shown as means of three months during the conduction of the experiments. 

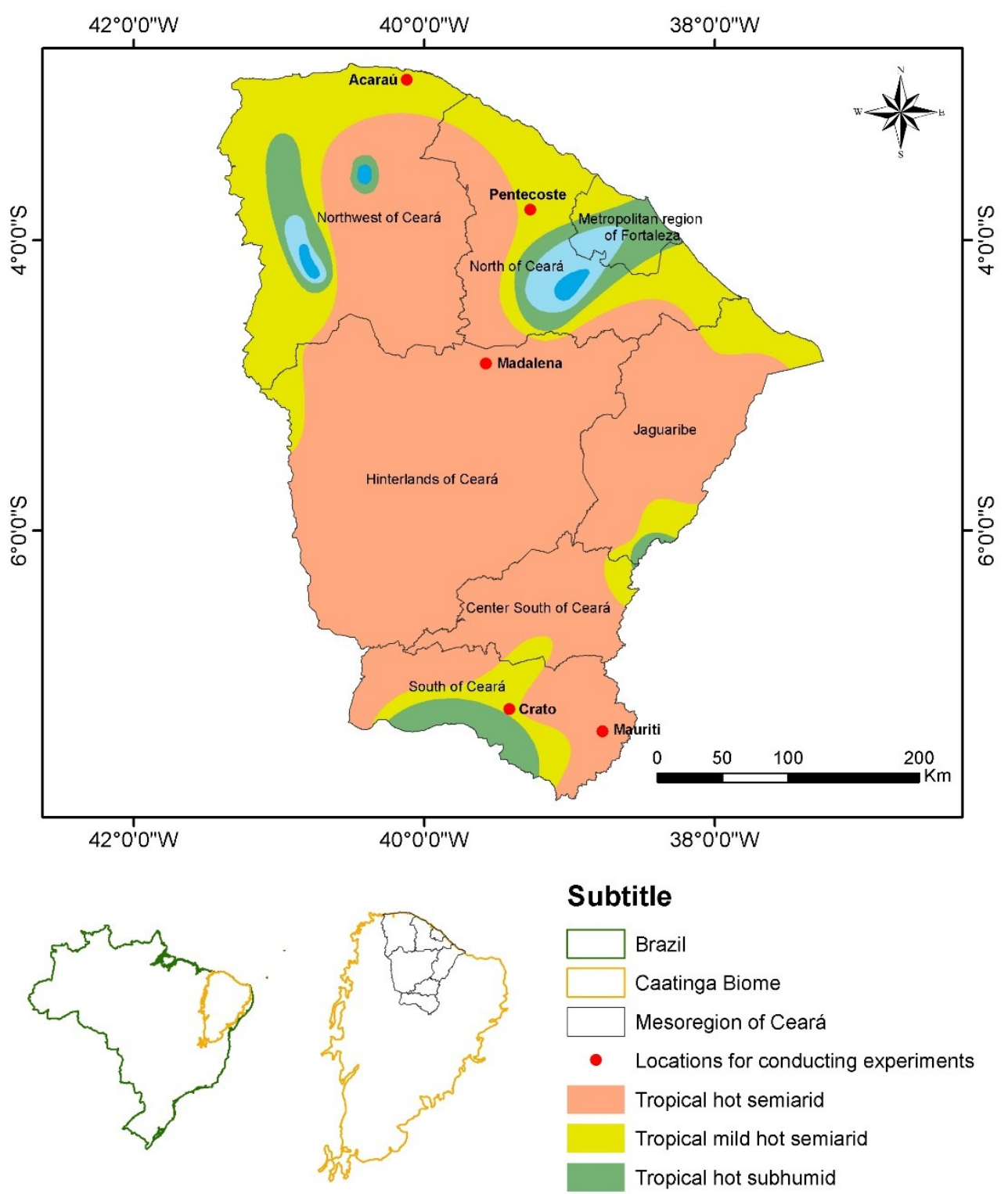

Subtitle

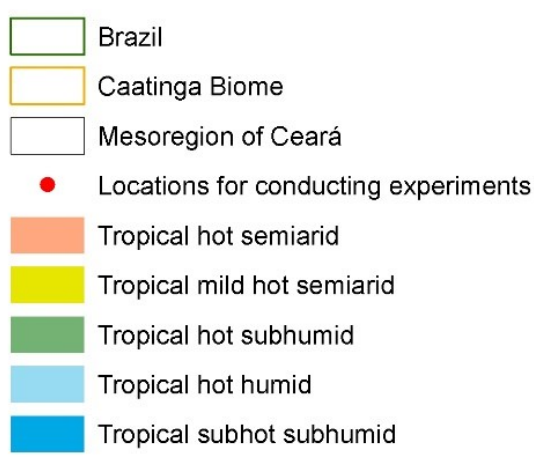

Figure 1. Climate classification and geographical distribution of the locations of evaluation of 20 cowpea genotypes in the state of Ceará, Brazil.

The genotypes were evaluated for grain yield $\left(\mathrm{kg} \mathrm{ha} \mathrm{h}^{-1}\right)$ in rainfed conditions, except in the municipality of Crato, where the crop was daily irrigated using a conventional stationary sprinkle system for 30 minutes. The sowing time varied from February to April, according to the rainy season, except in Crato, where it was done in August, outside the period of higher rainfall depths (Table 1). Therefore, plants in this environment required irrigation.
The assays were conducted in a randomized block experimental design with four replications. The experimental plots of all assays were similar, as required by the Brazilian Ministry of Agriculture, Livestock, and Supply (MAPA), with dimensions of $3.2 \times 5.0 \mathrm{~m}$, consisted of four 5 -meter rows, using the two central rows for the evaluations. The spacing was $0.80 \mathrm{~m}$ between rows and $0.25 \mathrm{~m}$ between plants (20 plants per row). Four seeds were sowed per pit and a thinning was done at 15 days after the sowing, leaving one plant per pit. 
Table 2. Cowpea genotypes and their respective parental and/or precedence and commercial subclasses.

\begin{tabular}{|c|c|c|c|}
\hline$\overline{\text { Code }}$ & Genotypes & Parental/Precedence & Commercial Subclass \\
\hline 1 & MNC00-586F-303-9 ${ }^{(1)}$ & Capela x IT85F-2687 & Green \\
\hline 2 & MNC00-595F-2 ${ }^{(1)}$ & BRS-Bragança x GV-10-91-1-1 & Green \\
\hline 3 & $\mathrm{MNC} 00-595 \mathrm{~F}-27^{(1)}$ & BRS-Bragança x GV-10-91-1-1 & Green \\
\hline 4 & MNC05-835B-15 ${ }^{(1)}$ & MNC00-599F-2 x MNC99-537F-14-2 & Green \\
\hline 5 & MNC05-835B-16 ${ }^{(1)}$ & MNC00-599F-2 x MNC99-537F-14-2 & Green \\
\hline 6 & MNC05-841B-49 ${ }^{(1)}$ & MNC00-599F-9 x MNC99-537F-14-2 & Green \\
\hline 7 & MNC05-847B-123 ${ }^{(1)}$ & MNC00-599F-11 x MNC99-537-14-2 & Green \\
\hline 8 & MNC05-847B-126 ${ }^{(1)}$ & MNC00-599F-11 x MNC99-537-14-2 & Green \\
\hline 9 & MNC99-541F-15 ${ }^{(1)}$ & TE93-210-13F $\times$ TE96-282-22G & White \\
\hline 10 & BRS Guariba ${ }^{(2)}$ & IT85F-2687 x TE87-98-8G & White \\
\hline 11 & BRS Tumucumaque ${ }^{(2)}$ & TE96-282-22G x IT87D-611-3 & White \\
\hline 12 & BRS Xiquexique ${ }^{(2)}$ & TE87-108-6G $\times$ TE87-98-8G & White \\
\hline 13 & Paulistinha ${ }^{(2)}$ & Juazeiro-CE & Canapu \\
\hline 14 & Vagem Roxa-THE $^{(2)^{*}}$ & Teresina-PI & White \\
\hline 15 & Azulão-MS ${ }^{(2)^{*}}$ & Dourados-MS & Azulão \\
\hline 16 & Sempre Verde-CE ${ }^{(2)^{*}}$ & Fortaleza-CE & Sempre-verde \\
\hline 17 & BRS Aracê (2) & MNC00-599F-11 x MNC99-537F-14-2 & Green \\
\hline 18 & Pingo-de-Ouro-1-2 ${ }^{(1)}$ & Iguatu-CE & Canapu \\
\hline 19 & $\mathrm{MNC} 02-701 \mathrm{~F}-2^{(1)}$ & TE93-210-13F x (TE96-282-22G x Costelão) & White \\
\hline 20 & MNC99-510F-16-1 ${ }^{(1)}$ & Paulista $\times$ TE90-180-88F & Sempre-verde \\
\hline
\end{tabular}

${ }^{(1)}$ Lines; ${ }^{(2)}$ Cultivars; *Control.

Soil preparation were done as needed for each area, using conventional practices of plowing and harrowing. Soil fertilization was done at planting, using potassium chloride and simple superphosphate; topdressing consisted of a nitrogen (urea) application at 15 days after sowing. The fertilizers were applied according to recommendations for the soil of the experimental area of each environment based on soil chemical analysis. Weed and pest control was done as needed, using manual weeding and insecticide applications, respectively. The pods were manually harvested when they were at the maturation stage for marketing as green grains, i.e., when the grains presented $60 \%$ to $70 \%$ moisture, considering the individual maturation pattern of each genotype (SOUSA et al., 2015).

Individual analyses of variance were done for each environment to assess the homogeneity of residual variances, considering the following model:

$$
\bar{Y}_{i j}=\mu+G_{i}+B_{j}+e_{i j}
$$

where $Y_{i j}$ is the phenotypic mean of the $\mathrm{i}$-th genotype in the $\mathrm{j}$-th block; $\mu$ is the general mean; $G_{i}$ is the effect of the $\mathrm{i}$-th genotype; $B_{j}$ is the effect of the $\mathrm{j}$-th block; $e_{i j}$ is the effect of the error associated to the $\mathrm{i}$-th genotype in the $\mathrm{j}$-th block.

Then, joint analysis of variance was done, considering the effects of genotypes and environments to determine possible genotypeenvironment interactions. The selective accuracy (RESENDE; DUARTE, 2007) was estimated as SA $=(1-1 / F)^{1 / 2}$, where $F$ is the $\mathrm{F}$ test value for the genotype.

The GGE biplot multivariate analysis was based on phenotypic means, considering the following model:

$$
\bar{Y}_{i j}-\mu=G_{i}+E_{j}+G_{i j},
$$


where $\bar{Y}_{i j}$ is the phenotypic mean of the genotype $i$ in the environment $j ; \mu$ is the general mean; $G_{i}$ is the effect of genotype $i ; E_{j}$ is the effect of environment $j$; and $G E_{i j}$ is the effect of the interaction between genotype $i$ and environment $j$.

The GGE biplot model does not separate genotypic effects $(\mathrm{G})$ from effects of the genotypeenvironment interaction $(\mathrm{G} \times \mathrm{E})$, keeping together in two multiplicative terms, represented by the following equation:

$$
Y_{i j}-\mu-\beta_{j}=g_{1 i} e_{l j}+g_{i 2} e_{2 j}+\varepsilon_{i j}
$$

where $Y_{i j}$ is the expected yield of the genotype $i$ in the environment $j$; $\mu$ is the general mean of the observations; $\beta_{j}$ is the main effect of the environment $j ; g_{l i}$ and $e_{l j}$ are the main scores of the i-th genotype in the j-th environment, respectively; $g_{i 2}$ and $e_{2 j}$ are secondary scores for the genotype $i$ and environment $j$, respectively; and $\varepsilon_{i j}$ is the residue that was not explained by both effects (noise).

Thus, the construction of the GGE biplot model is done by simple dispersion of $g_{l i}$ and $g_{i 2}$ for genotypes, and $e_{l j}$ and $e_{2 j}$ for environments, by singular value decomposition (SVD), according to the equation:

$$
Y_{\mathrm{ij}}-\mu-\beta_{\mathrm{j}}=\lambda_{1} \xi_{\mathrm{il}} \eta_{\mathrm{lj}}+\lambda_{2} \xi_{\mathrm{i} 2} \eta_{2 \mathrm{j}}+\varepsilon_{\mathrm{ij}}
$$

where $\lambda_{1}$ and $\lambda_{2}$ are the higher eigenvalues of first and second principal components, $\left(P C E_{1}\right.$ and $P C E_{2}$, respectively); $\xi_{i 1}$ and $\xi_{i 2}$ are the eigenvalues of the i-th genotype for $P C E_{1}$ and $P C E_{2}$, respectively; and $\eta_{1 \mathrm{j}}$ and $\eta_{2 j}$ are the eigenvalues of the $\mathrm{j}$-th environment for $P C E_{l}$ and $P C E_{2}$, respectively.

The information relation (IR) proposed by Yan and Tinker (2006) is estimated to evaluate the fit of a biplot and show the patterns of a double entry table. The IR can be calculated for each principal component using the proportion of the total variance explained by each principal component multiplied by $k$ ( $k$ PC). When there is no correlation between environments, all $k$ PC should be completely independent, and the proportion of total variance explained by each PC should be precisely $1 / k$. When there is correlation between environments, the proportion of variation explained by the first PC should be higher than $1 / k$, and the variation explained by the other PC should be lower than or equal to $1 / k$. A PC with $I R>1$ contains patterns (associations between environments); a PC with $I R=1$ does not include patterns, but can contain some independent information; and a PC with $I R<1$ does not contain patterns or information (YAN, 2011).

All analyses were done using the $\mathrm{R}$ program, with the aid of the GGE biplot GUI package (R CORE TEAM, 2016).

\section{RESULTS AND DISCUSSION}

The joint analyses of variance showed significant differences $(\mathrm{p}<0.01)$ for the effects of the genotypes, environments, and $\mathrm{G} \times \mathrm{E}$ (Table 3 ), denoting differences in the green grain yield responses of the genotypes; sufficient differences between locations to discriminate the genotypes; and different responses of genotypes in the different locations. Therefore, the genotypes presented no similar development to all environments due to the ecogeographical differences between the environments tested (Table 1), resulted from their different altitude, location, and climate (rainfall and temperature).

Barros et al. (2016) and Santos et al. (2017a) found similar results for grain yield of cowpea genotypes in multi-environmental assays in the state of Mato Grosso of Sul, Brazil, showing that edaphoclimatic factors had high effect on genotype adaptability and stability and additional analyses are needed to identify genotypes that are adapted to large number of locations.

Table 3. Joint analysis of variance for green grain yield $\left(\mathrm{kg} \mathrm{ha}^{-1}\right)$ of 20 cowpea genotypes evaluated in cultivation value and

\begin{tabular}{|c|c|c|}
\hline Source of variation & Degrees of freedom & Mean Squares \\
\hline Block & 3 & $368,832.1$ \\
\hline Genotypes (G) & 19 & $828,533.9^{* *}$ \\
\hline Environments (E) & 4 & $9,905,440.7^{* *}$ \\
\hline $\mathrm{G} \times \mathrm{E}$ & 76 & $248,812.9^{* *}$ \\
\hline Residue & 297 & $158,262.3$ \\
\hline Selective Accuracy (SA) & - & 0.73 \\
\hline Mean & - & 926.45 \\
\hline
\end{tabular}
use assays in five locations in the state of the state of Ceará, Brazil.

$* *$ Significant at $\mathrm{p}<0.01$ by the $\mathrm{F}$ test.

Rev. Caatinga, Mossoró, v. 33, n. 2, p. 321 - 331, abr. - jun., 2020 
The results indicated the need for further evaluations of the main effects and $\mathrm{G} \times \mathrm{E}$, which cannot be obtained by standard analysis of variance, despite it had shown high selective accuracy according to Resende and Duarte (2007). Selective accuracy is a parameter that shows the quality of the information (experimental precision) and procedures used to predict genetic values (PIMENTEL et al., 2014).

The additive effect of genotypes and the multiplicative effect of the interaction are grouped in the GGE analysis and subjected concomitantly to analysis of principal components (YAN et al., 2000). The analysis of principal components showed that the two first components were responsible for $72.17 \%$ of the total variation in green grain yield (Table 4). Therefore, these results showed that the multivariate technic of principal components explained a large proportion of sum of squares of genotypes and $\mathrm{G} \times \mathrm{E}$, showing the high efficiency of the methodology (SANTOS et al., 2017b).

Table 4. Singular value, variation explained, proportion accumulated, and information relation (IR) for the five principal components (PC) of the GGE biplot analysis for 20 cowpea genotypes evaluated in cultivation value and use assays in five locations in the state of Ceará, Brazil.

\begin{tabular}{lcccc}
\hline PC & Singular Value & \% explained & \% accumulated & IR \\
\hline 1 & $209,924.8$ & 51.84 & 51.84 & 3.56 \\
2 & $82,305.5$ & 20.33 & 72.17 & 1.43 \\
3 & $71,534.5$ & 17.66 & 89.83 & 1.16 \\
4 & $29,155.2$ & 7.20 & 97.03 & 0.62 \\
5 & $12,020.1$ & 2.97 & 100.0 & 0.14 \\
\hline
\end{tabular}

Oliveira et al. (2017) used the same procedure to evaluate adaptability and stability of grain zinc contents in 12 cowpea genotypes and found high efficiency for the two first components $(77.8 \%)$. However, Sousa et al. (2018) evaluated the effect of the $\mathrm{G} \times \mathrm{E}$ on grain yield of elite lines of cowpea and found lower efficiency when considering the two first components (66\%). These different methodology efficiency percentages in the explanation of effects of genotypes and $\mathrm{G} \times \mathrm{E}$ depend on the characters, genotypes, and environments (locations or crop seasons) evaluated (OLIVEIRA et al., 2017).

The IR of the three first principal components were above 1 (Table 4), denoting that they are effectively the most important (informative) to explain the total variation of the data. Oliveira et al. (2017) reported that the existence of patterns in the two first principal components confirms the results of the $F$ test in the joint analysis. Similar to the present study, they found significant differences for $\mathrm{G} \times \mathrm{E}$ effects on green grain yields, confirming the different responses of genotypes to environmental changes, thus justifying the application of the GGE biplot method to evaluate their adaptability.

The GGE biplot which-won-where (Figure 2A) based on the two first principal components provided a visualization of patterns, allowing the identification of genotypes with superior development for specific environments. According to this graph, the genotypes 1 (MNC00-586F-303-9), 2 (MNC00-595F-2), 6 (MNC05-841B-49), 7 (MNC05847B-123), 9 (MNC99-541F-15), 12 (BRS
Xiquexique), 13 (Paulistinha), and 19 (MNC02-701F $-2)$, in the vertices of the polygon are the most responsive to their respective environments near their vertices. However, they can present best or worse performance in one or more environments (YAN; TINKER, 2006), and are more suitable for specific recommendations. Contrastingly, the other genotypes located next to the origin, i.e., within the polygon, are less responsive to environmental stimuli and, thus, more suitable when the objective is a broad adaptation.

The GGE biplot method has the advantage of assisting in delimit agronomical areas by identifying mega-environments, defined as groups of environments with similar $\mathrm{G} \times \mathrm{E}$ and, consequently, with little change in the ranking of genotypes (CARVALHO et al., 2016). The biplot which-wonwhere also allows the visual grouping of environments and determines the genotypes with best mean performances for each mega-environment (YAN et al., 2007). Considering the results of the projections (Figure 2A), three mega-environments were formed: the first represented by Pentecoste, Acaraú, and Mauriti, the second by Crato, and the third by Madalena. The lines 9 (MNC99-541F-15), 2 (MNC00-595F-2) and 6 (MNC05-841B-49) located in the vertices of polygon of first, second, and third mega-environment, respectively, presented the best mean performance within the mega-environments formed. Oliveira et al. (2017) reported that the quantity of mega-environments formed depends on the number and characteristics of genotypes and environments and on the evaluated character. 

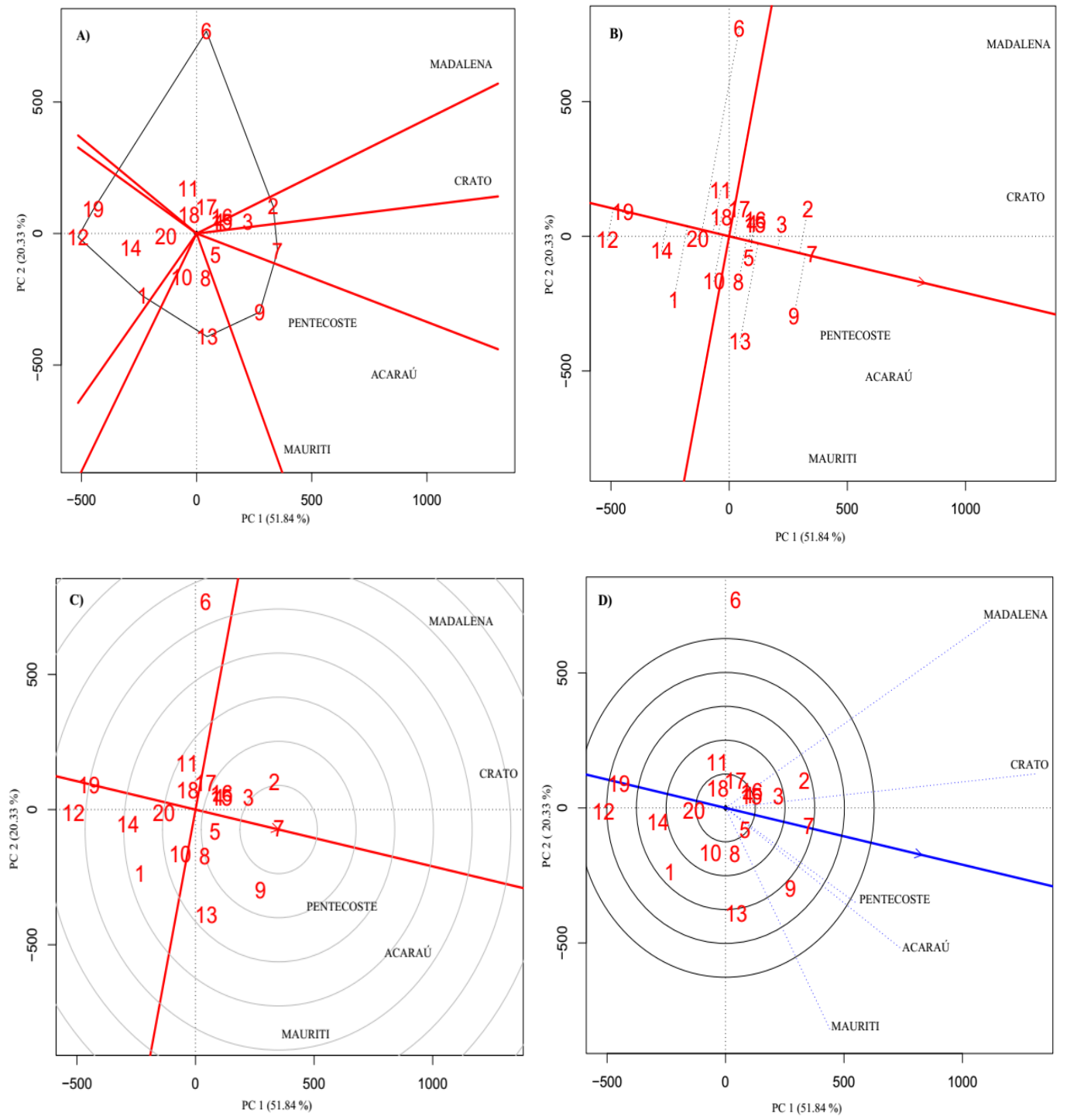

Figure 2. GGE biplot analysis for grain yield of 20 cowpea genotypes (1 to 20) evaluated in five locations of the state of Ceará, Brazil (Acaraú, Pentecoste, Crato, Mauriti, and Madalena). A) which-won-where; B) mean vs. stability; C) ideal genotype; D) discrimination $v s$. representativity.

According to the biplot mean vs. stability (Figure 2B), the higher the projection of a genotype in relation to the axis of $\mathrm{PC} 1$, the lower its stability; contrastingly, the farther the genotype is from the axis of PC2 (perpendicular to the axis PC1), the more productive it tends to be. Thus, the line 6 (MNC05-841B-49) was the most instable of the genotypes evaluated and expressed lower productive performance than the mean; however, it had advantageous performance in relation to other genotypes grown in the environment Madalena. The lines 7 (MNC05-847B-123), 19 (MNC02-701F-2) and 20 (MNC99-510F-16-1) are highly stable; however, the first stood out with higher green grain yield. Moreover, the lines 2 (MNC00-595F-2), 3 (MNC00-595F-27), 4 (MNC05-835B-15), 5 (MNC05-835B-16), and 8 (MNC05-847B-126), and the control cultivars 15 (Azulão-MS) and 16
(Sempre Verde-CE) stood out, presenting higher stabilities combined with higher yields. Thus, the yield of these control cultivars was surpassed by lines 7 (MNC05-847B-123), 2 (MNC00-595F-2), and 3 (MNC00-595F-27).

According to Yan and Tinker (2006), the high stability of the genotypes is significant only when combined with mean performance. Thus, lines 19 (MNC02-701F-2) and 20 (MNC99-510F-16-1), which showed high stability by presenting low projections of the axis 1 , are not good options for green grain production in Ceará, since they stand out only by having high consistent relative performance. However, the line 7 (MNC05-847B-123) had high productive performance combined with high consistent relative performance (high stability), and is a good option, since it had adaptability combined with stability, and surpassed the controls 15 (Azulão- 
MS) and 16 (Sempre Verde-CE) in both aspects.

An ideal genotype present high mean performance for the studied character combined with high stability in all environments tested (YAN; TINKER, 2006). Although this is a hypothetical model, it is used as reference to identify an ideotype (SANTOS et al., 2017b). Genotypes located nearer the center of concentric circles are the most desirable (Figure 2C); thus, the line 7 (MNC05-847B-123), which had high stability and yield, was close to an ideal genotype, proving to be a promising genotype for green grain production in the state of Ceará.

The lines 3 (MNC00-595F-27) and 2 (MNC00-595F-2), in the limit of the first concentric circle, followed by lines 9 (MNC99-541F-15), 5 (MNC05-835B-16), 8 (MNC05-847B-126), and 4 (MNC05-835B-15), and cultivars 15 (Azulão-MS) and 16 (Sempre Verde-CE), in the second concentric circle, stood out by presenting similar performance to the ideal genotype regarding grain yield and phenotypic stability. The lines 9 (MNC99-541F-15), 2 (MNC00-595F-2), and 3 (MNC00-595F-27) presented superior productive performance to controls 15 (Azulão-MS) and 16 (Sempre Verde$\mathrm{CE})$, but the two first did not the surpassed them in terms of stability. Therefore, these lines are recommended only for the studied environments (specific adaptability), whereas the line 3 (MNC00$595 \mathrm{~F}-27$ ) had similar stability to controls and can be recommended for the whole state of Ceará. Thus, the recommendation of the best genotypes should not be based only on their high productive performance, but also on their stability.

An ideal test environment should discriminate superior genotypes and be representative of all test environments (SANTOS et al., 2017b). The GGE biplot shows the discriminatory power of a test environment based on the length of its vector (YAN; HOLLAND, 2010). The discrimination vs. representativity graph (Figure 2D) showed that the environments Madalena and Crato had higher vectors and, thus, higher discriminatory power; Mauriti and Acaraú presented moderate discriminatory power; and Pentecoste lower discriminatory power. This denotes that the environment Pentecoste hindered the genotypical differentiation.

According to Yan et al. (2007) and Yan and Tinker (2006), environments can be classified as discriminative and representative (useful to select superior adapted genotypes); discriminative and not representative (useful to discard instable genotypes); and not discriminative and not representative (not useful as test environments). Regarding the representativity, the test environments that presented small angles with mean environment axis (line that crosses the mean environment and the origin of the biplot) are more representative (YAN; TINKER, 2006); thus, the environments Crato, Pentecoste, and Acaraú were the most representative ones (Figure
2D).

The results showed that the environment Crato was discriminative and representative and, therefore, closer to an ideal location for recommendation of superior genotypes focused on higher green-grain cowpea yields, i.e., this environment favors the selection of superior adapted genotypes. However, the irrigated crop may have affected the choice of this municipality as the closer to an ideal environment, since the constant irrigation, mainly at more critical stages of development of plants (flowering and grain filing) may have improved the yield.

Moreover, Madalena and Mauriti are useful to discard instable genotypes, since these are discriminative and not representative environments (YAN; TINKER, 2006). Pentecoste was not discriminative, but representative, indicating that despite this environment cannot be used to assess genetic variation between genotypes (BLANCHE; MYERS, 2006), it can represent the conditions of other locations of evaluations. None of the environments was simultaneously not discriminative and not representative, making impossible the discarding of environments based on this criterion.

The vectors of the environments (lines that connect environments up to the origin of the biplot) showed the similarity between environments in discriminate the genotypes. According to Yan and Tinker (2006), the distance between two environments measures its dissimilarity in the discrimination of genotypes. Therefore, Pentecoste and Acaraú, which had close environment vectors (Figure 2D), were similar in the discrimination of genotypes. Although these environments are in different mesoregions, they have the same climate (Figure 1) and showed similar results. Consequently, one of the environments can be discarded in further evaluations to provide savings in physical, financial, and human resources.

Despite the geographical proximity between the environments Crato and Mauriti, both located in the same mesoregion (South of Ceará) (Figure 1), they were not similar in the discrimination of genotypes, exhibiting a considerable distance between their vectors. This was probably due to the effect of the sowing time, which was during the dry season in Crato (August of 2016) and during the rainy season in Mauriti (February of 2017); the irrigation used in the experiment conducted in Crato; and the different climate and temperature between Mauriti (tropical hot semiarid, with mean temperature of $25.2^{\circ} \mathrm{C}$ ) and Crato (tropical mild hot semiarid, with mean temperature of $21.1{ }^{\circ} \mathrm{C}$ ); and their soil type.

The GGE biplot discrimination vs. representativity (Figure 2D) showed the relation between environments according to the angle formed between their vectors; angles $<90^{\circ}$ denote strong positive correlation between environments, angles 
$=90^{\circ}$ denote no correlation between environments, and angles $>90^{\circ}$ denote strong negative correlation between environments (YAN; TINKER, 2006). Therefore, most environments were correlated positively, except Madalena and Mauriti, which had angle $>90^{\circ}$. This indicates a $\mathrm{G} \times \mathrm{E}$ of complex nature only between Madalena and Mauriti, i.e., the ranking of genotypes changed only in these two environments. Moreover, there was predominance of simple nature interaction between environments, thus, the recommendation can be done to a broader area without significant consequences.

The similarity between Pentecoste and Acaraú confirms the strong correlation between these environments and the similar classification of genotypes. According to Yan et al. (2007), some environments cannot provide exclusive information due to their similarity with other environments in the separation and classification of genotypes, and can be discarded, providing a decrease in evaluation costs. The identification and discarding of these noninformative and redundant environments should be based on data of several years.
A genotype can present high adaptability and stability, but low productive performance, denoting the importance of mean yield analyzes. The gathering of information of GGE biplot analyses and mean yields showed that the lines 7 (MNC05-847B123), 2 (MNC00-595F-2), and 3 (MNC00-595F-27), which were adapted to the local conditions and had production stability, presented higher mean yields than the controls 14 (Vagem Roxa-THE), 15 (Azulão -MS), and 16 (Sempre Verde-CE) (Table 5). These results confirm the precision and sensitivity of the GGE biplot methodology and indicate that these lines should be recommended for the state of Ceará, focused on green grain production of cowpea.

The line 2 (MNC00-595F-2) in Crato presented the highest yield found in the experiments, denoting a high adaptation to this environment. The highest green grain yields found for lines 2 (MNC00 -595F-2), 3 (MNC00-595F-27), 7 (MNC05-847B123 ), and 9 (MNC99-541F-15) are possibly due to the genetic superiority of the genotypes, which results in higher mean environmental yields.

Table 5. Mean green grain yields $\left(\mathrm{kg} \mathrm{ha}^{-1}\right)$ of 20 cowpea genotypes evaluated in cultivation value and use assays in five locations in the state of Ceará, Brazil.

\begin{tabular}{|c|c|c|c|c|c|c|c|c|c|c|c|c|}
\hline \multirow{3}{*}{$\frac{\text { Code }}{1}$} & \multirow{3}{*}{$\begin{array}{c}\text { Genotypes } \\
\text { MNC00-586F-303-9 }\end{array}$} & \multicolumn{10}{|c|}{ Environments } & \multirow{3}{*}{$\begin{array}{c}\begin{array}{c}\text { Overall } \\
\text { mean }\end{array} \\
770\end{array}$} \\
\hline & & \multicolumn{2}{|c|}{ Acaraú } & \multicolumn{2}{|c|}{ Pentecoste } & \multicolumn{2}{|c|}{ Crato } & \multicolumn{2}{|c|}{ Mauriti } & \multicolumn{2}{|c|}{ Madalena } & \\
\hline & & 781 & $\mathrm{Bb}$ & 563 & $\mathrm{Da}$ & 896 & Ad & 715 & $\mathrm{Cb}$ & 893 & $\mathrm{Ab}$ & \\
\hline 2 & MNC00-595F-2 & 1064 & $\mathrm{Ca}$ & 631 & $\mathrm{Da}$ & 2413 & $\mathrm{Aa}$ & 634 & $\mathrm{Db}$ & 1629 & $\mathrm{Ba}$ & 1274 \\
\hline 3 & MNC00-595F-27 & 1005 & $\mathrm{Ca}$ & 930 & $\mathrm{Da}$ & 1196 & $\mathrm{Bc}$ & 722 & $\mathrm{~Eb}$ & 1821 & $\mathrm{Aa}$ & 1135 \\
\hline 4 & MNC05-835B-15 & 938 & $\mathrm{Ca}$ & 640 & $\mathrm{Da}$ & 1765 & $\mathrm{Ab}$ & 322 & Ec & 1053 & $\mathrm{Bb}$ & 944 \\
\hline 5 & MNC05-835B-16 & 929 & $\mathrm{Ca}$ & 583 & $\mathrm{Ea}$ & 1384 & Ac & 751 & $\mathrm{Db}$ & 1314 & $\mathrm{Bb}$ & 992 \\
\hline 6 & MNC05-841B-49 & 646 & $\mathrm{Cb}$ & 248 & $\mathrm{Db}$ & 1257 & $\mathrm{Bc}$ & 104 & $\mathrm{Ed}$ & 1966 & $\mathrm{Aa}$ & 844 \\
\hline 7 & MNC05-847B-123 & 1350 & $\mathrm{Ca}$ & 875 & $\mathrm{Da}$ & 1438 & $\mathrm{Bc}$ & 739 & $\mathrm{~Eb}$ & 1780 & $\mathrm{Aa}$ & 1236 \\
\hline 8 & MNC05-847B-126 & 1139 & $\mathrm{Ba}$ & 807 & $\mathrm{Da}$ & 1294 & Ac & 512 & $\mathrm{~Eb}$ & 1115 & $\mathrm{Cb}$ & 973 \\
\hline 9 & MNC99-541F-15 & 1099 & $\mathrm{Ca}$ & 676 & $\mathrm{Ea}$ & 1712 & $\mathrm{Ab}$ & 1065 & $\mathrm{Da}$ & 1319 & $\mathrm{Bb}$ & 1174 \\
\hline 10 & BRS Guariba & 1091 & $\mathrm{Ba}$ & 608 & $\mathrm{Ea}$ & 880 & $\mathrm{Cd}$ & 701 & $\mathrm{Db}$ & 1290 & $\mathrm{Ab}$ & 914 \\
\hline 11 & BRS Tumucumaque & 793 & $\mathrm{Cb}$ & 343 & $\mathrm{~Eb}$ & 1416 & $\mathrm{Ac}$ & 389 & $\mathrm{Dc}$ & 1211 & $\mathrm{Bb}$ & 830 \\
\hline 12 & BRS Xiquexique & 555 & $\mathrm{Bb}$ & 238 & $\mathrm{~Eb}$ & 407 & Dd & 489 & $\mathrm{Cc}$ & 878 & $\mathrm{Ab}$ & 513 \\
\hline 13 & Paulistinha & 1422 & $\mathrm{Aa}$ & 588 & $\mathrm{Ea}$ & 1077 & $\mathrm{Cc}$ & 855 & $\mathrm{Da}$ & 1174 & $\mathrm{Bb}$ & 1023 \\
\hline 14 & Vagem Roxa-THE & 769 & $\mathrm{Cb}$ & 222 & $\mathrm{~Eb}$ & 805 & $\mathrm{Bd}$ & 627 & $\mathrm{Db}$ & 1032 & $\mathrm{Ab}$ & 691 \\
\hline 15 & Azulão-MS & 1323 & $\mathrm{Ba}$ & 701 & $\mathrm{Da}$ & 914 & $\mathrm{Cd}$ & 504 & $\mathrm{~Eb}$ & 1737 & $\mathrm{Aa}$ & 1036 \\
\hline 16 & Sempre Verde-CE & 973 & $\mathrm{Ca}$ & 606 & $\mathrm{Ea}$ & 1277 & $\mathrm{Bc}$ & 628 & $\mathrm{Db}$ & 1546 & $\mathrm{Aa}$ & 1006 \\
\hline 17 & BRS Aracê & 852 & $\mathrm{Ca}$ & 435 & $\mathrm{Ea}$ & 1296 & $\mathrm{Bc}$ & 625 & $\mathrm{Db}$ & 1449 & $\mathrm{Aa}$ & 931 \\
\hline 18 & Pingo-de-Ouro-1-2 & 911 & $\mathrm{Ca}$ & 505 & $\mathrm{Ea}$ & 1087 & $\mathrm{Bc}$ & 532 & $\mathrm{Db}$ & 1392 & $\mathrm{Ab}$ & 885 \\
\hline 19 & MNC02-701F-2 & 611 & $\mathrm{Bb}$ & 552 & $\mathrm{Ca}$ & 733 & $\mathrm{Ad}$ & 80 & $\mathrm{Db}$ & 713 & $\mathrm{Ab}$ & 538 \\
\hline 20 & MNC99-510F-16-1 & 800 & $\mathrm{Cb}$ & 463 & $\mathrm{Ea}$ & 943 & $\mathrm{Bd}$ & 641 & $\mathrm{Db}$ & 1262 & $\mathrm{Ab}$ & 822 \\
\hline
\end{tabular}

Means followed by the same uppercase letter horizontally and the same lowercase letter vertically constitute a statistically homogeneous group using the Scott-Knott test at $\mathrm{p}<0.05$.

\section{CONCLUSIONS}

The lines 2 (MNC00-595F-2), 3 (MNC00595F-27), 7 (MNC05-847B-123) and 9 (MNC99541F-15), presented higher productive performances and are indicated for further evaluations in cowpea breeding programs focused on green grain production.
The environments Pentecoste and Acaraú were similar in the discrimination of genotypes, whereas the environments Crato and Mauriti were not similar in the discrimination of genotypes.

The lines 7 (MNC05-847B-123) and 3 (MNC00-595F-27) of cowpea can be recommended for green grain production in the state of Ceará, Brazil, due their high grain yield, adaptability, and 
genotypical stability.

The line 2 (MNC00-595F-2) can be recommended specifically for Crato, since it combined good stability and adaptability to high grain yield in this environment

\section{ACKNOWLEDGEMENTS}

The authors thank the Embrapa Mid-North for the financial support, and for providing the seeds for the experiments; and to the Foundation for Support of Scientific and Technological Development of the State of Ceará (Funcap) for granting scholarships.

\section{REFERENCES}

ADEWALE, B. D. et al. Genotypic variability and stability of some grain yield components of Cowpea. African Journal of Agricultural Research, 5: 874$880,2010$.

BARROS, L. M. A. et al. Bayesian approach increases accuracy when selecting cowpea genotypes with high adaptability and phenotypic stability. Genetics and Molecular Research, 15: 1-11, 2016.

BLANCHE, S. B.; MYERS, G. O. Identifying discriminating locations for cultivar selection in Louisiana. Crop Science, 46: 946-949, 2006.

CARVALHO, L. C. B. et al. Evolution of methodology for the study of adaptability and stability in cultivated species. African Journal of Agricultural Research, 11: 990-1000, 2016.

CENTRAIS DE ABASTECIMENTO DO CEARÁ CEASA. Histórico de ofertas de produtos em 2016. Disponível em: < http://www.ceasa-ce.com.br/ index.php/historicoofertas>. Acesso em: 10 jul. 2018.

CRUZ, C. D.; CARNEIRO, P. C.; REGAZZI, A. D. Modelos biométricos aplicados ao melhoramento genético. 3. ed. Viçosa, MG: UFV, 2014. 668 p.

FREIRE FILHO, F. R. et al. A cultura: Aspectos socioeconômico. In: DoVALE, J. C.; BERTINI, C.; BORÉM, A. (Eds.). Feijão-caupi: do plantio à colheita. 1. ed. Viçosa, MG: UFV, 2017. v. 1 cap. 1, p. 9-34.

MUTHONI, J.; SHIMELIS, H.; MELIS, R. Genotype $\mathrm{x}$ Environment interaction and stability of potato tuber yield and bacterial wilt resistance in Kenya. American Journal of Potato Research, 92: 367-378, 2015.
OLIVEIRA, D. S. V. et al. Adaptability and stability of the zinc density in cowpea genotypes through GGE-Biplot method. Revista Ciência Agronômica, 48: 783-791, 2017

PIMENTEL, A. B. J. et al. Estimação de parâmetros genéticos e predição de valor genético aditivo de trigo utilizando modelos mistos. Pesquisa Agropecuária Brasileira, 49: 882-890, 2014.

R CORE TEAM. R: A language and environment for statistical computing. $R$ Foundation for Statistical Computing. Vienna, Áustria. 2016.

RESENDE, D. M.; DUARTE, J. B. Precisão e controle de qualidade em experimentos de avaliação de cultivares. Pesquisa Agropecuária Tropical, 37: 182-194, 2007.

ROCHA, M. M. et al. Adaptabilidade e estabilidade de genótipos de feijão-caupi quanto à produção de grãos frescos, em Teresina-PI. Revista Científica Rural, 14: 40-55, 2012.

ROCHA, M. M. O feijão-caupi para consumo na forma de grãos frescos. 2009. Agrosoft Brasil. Disponível em: http:// www.infoteca.cnptia.embrapa.br/infoteca/handle/ doc/574539. Acesso em: 10 jul. 2018.

SANTOS, A. et al. Selection of cowpea genotypes for Mato Grosso do Sul via GGE biplot and linear regression. Bioscienc Journal, 33: 631-638, 2017a.

SANTOS, A. et al. GGE Biplot projection in discriminating the efciency of popcorn lines to use nitrogen. Ciência e Agrotecnologia, 41: 22-31, $2017 b$

SANTOS, J. A. S. et al. Agronomic performance and genetic dissimilarity among cowpea (Vigna unguiculata (L.) Walp) genotypes. Global Advanced Research Journal of Agricultural Science, 3: 271-277, 2014.

SILVA, R. R.; BENIN, G. Análises Biplot: conceitos, interpretações e aplicações. Ciência Rural, 42: 1404-1412, 2012.

SOUSA, J. L. M. et al. Potencial de genótipos de feijão-caupi para o mercado de vagens e grãos verdes. Pesquisa Agropecuária Brasileira, 50: 392398, 2015.

SOUSA, M. B. et al. Genotype by environment interaction in cowpea lines using gge biplot method. Revista Caatinga, 31: 64-71, 2018.

YAN, W.; HOLLAND, J. B. A heritability-adjusted GGE biplot for test environment evaluation. 
Euphytica, 171: 355-369, 2010.

YAN, W. GGE biplot vs. AMMI analysis of genotype-by-envirom data analysis. Journal of the Indian Society of Agricultural Statistics, 65: 181193, 2011.

YAN, W. et al. Cultivar evaluation and megaenvironment investigation based on the GGE Biplot. Crop Science, 40: 597-605, 2000.

YAN, W. et al. GGE Biplot vs. AMMI analysis of genotype-by-enviromenment data. Crop Science, 47: 641-653, 2007.

YAN, W.; TINKER, N. Biplot analysis of multienvironment trial data: Principles and applications. Canadian Journal of Plant Science, 86: 623-645, 2006. 